EPPUR SI MUOVE: THI NKI NG “THE SOCIAL MOVEMENT”1

\title{
Laurence Cox
}

2011 was a good year for social movement researchers. The extraordinary events of the "Arab Spring" and the anti-austerity protests in Europe were widely covered in the mass media, noticed by students and even our colleagues. Of course the visibility or otherwise of social movements is historically conditioned, in academia as in popular awareness or in the media; within academia, the decades since 1968 have seen an increasingly institutionalised and systematic representation of collective action, and an increasingly established body of teachers, researchers, experts and otherwise "official" commentators on this pre-eminently unofficial activity.

In this process, social movement studies have become a minor, but familiar, field of academia, routinely included in general textbooks. As students' first encounter is increasingly in the classroom rather than as participants, the academic field has become increasingly self-sufficient. New researchers read official (and remarkably uncritical) histories of its origins, and they are presented with an increasingly closed canonical literature. Dialogue with the outside world can come to seem irrelevant; ${ }^{2}$ the outside world, whether movement participants or researchers in related fields, returns this lack of interest. ${ }^{3}$

This paper steps back from this situation to explore a wider history of ideas and an alternative, and older, usage of the phrase "social movement", grounded in a broader awareness of historical possibility and a more dialectical sense of social development than contemporary "social movement studies" usage. It then explores one way this figure of thought has been developed, in EP Thompson's Making of the English Working Class. Here the alternative understanding is deployed to great effect, covering a wide range of historical phenomena, their interconnections and transformations. Enormously influential on "history from below", studies of popular culture, and discussions of social class, Thompson's work shows a different way of thinking "social movement". Lastly, the paper uses this alternative understanding to think aspects of contemporary workingclass self-organisation in Ireland, which - because they do not behave as proper social movements ought - are hard to understand within mainstream approaches.

\footnotetext{
${ }^{1}$ This paper owes a great debt to Colin Barker, whose comradeship has been inspirational, and to long years of writing with the immensely rigorous Alf Nilsen. Neither, of course, are responsible for its weaknesses. Thanks are due to both and to John Krinsky for comments on an earlier draft.

${ }^{2}$ Geoghegan and Cox 2001.

${ }^{3}$ Bevington and Dixon 2005.
} 
This is quite an ambitious programme, and I'm not a specialist on nineteenth-century intellectual history, or the British Marxist historians. ${ }^{4}$ I hope to be able at least to sketch out the area and perhaps provoke some discussion of whether - as researchers or participants - it is wise to allow the routine academic processes of field-construction to define the limits of our own understanding.

\section{Thinking "the Social Movement"}

The phrase "social movement" is sometimes ascribed to the German political economist Lorenz von Stein in the title of his Geschichte der socialen Bewegung in Frankreich: von 1789 bis auf unsere Tage - "History of the social movement in France from 1789 until the present". ${ }^{5}$ In fact the term was already used in the 1840s; von Stein is nevertheless a good point to start the discussion.

The book is a study of revolutionary France, in the period which saw the Great Revolution of 1789-1815, the July Revolution of 1830 and the 1848 Revolution. Its three volumes are (I) Der begriff der Gesellschaft und die sociale Geschichte der französischen Revolution bis zum Jahre 1830 (The concept of society and the social history of the French Revolution up to 1830); (II) Die industrielle Gesellschaft. Der socialismus und communismus Frankreichs von 1830 bis 1848 (Industrial society: French socialism and communism from 1830 to 1848); (III) Das Königthum, die Republik, und die Souveränetät der französischen Gesellschaft seit der Februarrevolution 1848 (The monarchy, the republic, and the sovereignty of French society since the February Revolution of 1848). ${ }^{6}$

At first glance, this might not seem very surprising; the French Revolution is a defining moment of the modernity which social movements are said to characterize, sees classic developments in citizenship, the standardising of a particular repertoire of protest, and

\footnotetext{
${ }^{4}$ The late great Dorothy Thompson was kind enough to indicate that she felt an earlier version of this paper had substantially captured her husband's thinking on this matter (pers. comm.)

${ }^{5}$ Von Stein 1850-1855.

${ }^{6}$ Von Stein's interests were very wide-ranging. He also wrote on Schleswig-Holstein (Denkschrift über die Zollverhältnisse der Herzogthümer Schleswig und Holstein, mit besonderer Berücksichtigung eines Anschlusses derselben an den Zollverein, 1848); political science (System der Staatswissenschaft, 1852); public administration (Handbuch der Verwaltungslehre mit Vergleichung der Literatur und Gesetzgebung von Frankreich, England und Deutschland, 1870); the politics of the military (Die Lehre vom Heerwesen. Als Theil der Staatswissenschaft 1872); women and political economy (Die Frau auf dem Gebiete der Nationalökonomie, 1875; legal studies (Gegenwart und Zukunft der Rechts- und Staatswissenschaft Deutschlands, 1876); and landed property (Die drei Fragen des Grundbesitzes und ihre Zukunft: die irische, die continentale und die transatlantische Frage, 1881).
} 
so on. But the study of revolutions and that of social movements are now routinely separated off as separate fields. ${ }^{7}$

Indeed conventionally, "social movements" are praised for not being revolutionary; for operating in "civil society" rather than in the state, or for being non-violent as against the violence assumed to be defining of revolutions. They are often seen as taking the social order for granted: structured by the shifting alliance patterns of elites rather than creating their own, seeking the attention of the mainstream media rather than developing autonomous means of communication, governed by the availability of resources rather than trying to challenge their distribution, and so on.

\section{An Alternative Understanding}

Underlying von Stein's title is a rather different way of understanding "social movement" which this liberal university professor shared with political refugees and revolutionaries such as Marx and Engels. This was the common property of the European nineteenth century, a mode in which its intellectuals reflected on their shared experience. That experience was different in important ways from what underlies "social movement studies".

Firstly, it was an experience of frequently contested, and rapidly changing, "fields" within society (as against the remarkable stability of the basic institutional structures of western Europe and north America in the post-1968 period). This experience did not encourage seeing a particular institutional order as everlasting, or understanding movements as restricted to a particular location within that order. Intellectuals saw movements not only as challenging the given institutional order, but as transforming it; this was, after all, the legacy of the French Revolution. (It might be said that in some ways social movement studies embodies the legacy of the Cold War.)

Secondly, the basic nature of the state was constantly challenged and remade by society in the most dramatic ways - not only through democratic and socialist revolutions, but also through the nationalist movements which increasingly threatened the dynastic states of the day. And so a neat separation between "social movements" and "revolutions" was made neither by observers, nor by many participants, nor (come to that) by states and police forces. (After 1968, by contrast, many participants stressed their non-revolutionary aspirations as a source of self-defence in the years of Nixon and

\footnotetext{
${ }^{7}$ The formalistic "dynamics of contention" approach (McAdam, Tilly and Tarrow 2001) includes both along with wars, nationalism and many other kinds of conflict, but not as intrinsically related.
} 
Brezhnev, of the strategia della tensione and witchhunts against "sympathisers"; contemporary writing still often includes ritual condemnation of Marxism and revolutions.)

Thirdly, it was a period in which, partly for these reasons, social movements did not sustain the continuous institutional presence that characterises western societies since the defeat of fascism and even more since the $1960 \mathrm{~s} .{ }^{8}$ Instead, their situation alternated between periods of savage repression and revolutionary "waves". Although the conspiracy theory propagated by Abbé Barruel and reworked by Jules Michelet, in which all revolutions were the product of a hidden tradition of illuminist groups, ${ }^{9}$ encouraged political fantasies in which secret movements were ever-present, ${ }^{10}$ it was not until the end of the nineteenth century that actually-existing movements became a stable field with a constant "above-ground" existence and could be theorised using static concepts, in a handful of countries. For most of the world, this situation has arrived within recent memory, where it can be said to have arrived at all.

\section{The Social Movement and the Social Question}

One key to understanding the nineteenth-century usage of "social movement" lies in the shifting meanings of the word "social". As Williams notes, earlier usage was restricted in meaning, either to friendship in general, as in "socialising", or to the small circles of friends and acquaintances who counted in the world, a usage preserved in "high society" or "socialite". ${ }^{11}$

In the late eighteenth and the nineteenth century, this elite society - the world of Court, the aristocracy and the bourgeois novel - found itself increasingly under threat from the world of those who did not count. The "plebs", the menu peuple - tradesmen, artisans, workers, radicalised intellectuals and peasants - started to become actors upon the world stage, and the primary meaning of "society" shifted to encompass this sense of the vast world beyond high society.

Although elite members were of course closely familiar with the wider world individually - their own servants, hired hands, villagers and so on - this shift in usage marked an encounter with collective agency and a new kind of uncertainty: a sense that localized,

\footnotetext{
${ }^{8}$ The "social movements society” concept (Meyer and Tarrow 1998) illustrates this by contrast.

${ }^{9}$ The general theory is outlined in the title of John Robison's 1798 book, Proofs of a Conspiracy Against All the Religions and Governments of Europe, carried on in the secret meetings of Free Masons, Illuminati, and Reading Societies, collected from good authorities.

${ }^{10}$ Hutton 1999.

${ }^{11}$ Williams 1983.
} 
specific forms of domination are no longer enough, a lesson underlined by the revolutions that von Stein's dates mark. There was a need to understand that wider society in more abstract and general terms; this concern over the threat to social order from the social effects of capitalism is a foundational theme in sociology, from Tönnies and Durkheim to the Chicago school.

All this created a need to control, to take appropriate action, outside the customary means of social control and traditionalised routines which were breaking down. Society could be controlled through the increasing development of institutions of coercion modern police forces, the political police and the standing army; through disciplinary methods, whether Foucault's prison and asylum, modern medicine and psychiatry, or Thompson's work-discipline and religious sanctification of obedience; or through the (liberal, later Fabian) attempt to resolve underlying grievances and sources of tension.

"Social" in this sense is the referent of "the social question": the source of threats to "the social order" identified by those who looked at "society" with a bird's-eye perspective and were in a position to propose, and occasionally to take, action. It refers in particular to the unruly towns and cities of industrialising Europe, and within them to the uncontrolled and perhaps uncontrollable energies of social groups whose own internal life was seen as the source of the threat. That key word of the period, "mob", shortens Latin mobile vulgus, "the mobile crowd" - or, as it might also be translated, "the social movement"12.

The group which seemed most alien, with least to lose, and most threatening was the developing industrial working class; next to this, the "many-headed hydra" (Linebaugh 2001) of soldiers, sailors, slaves and traditional forms of manual labour; and Thompson's "demotic" groups- the craftspeople and small traders, journeymen and semi-proletarian peasants who filled out the complex "social" of nineteenth-century Europe.

"The social question", and with it, "the social movement", then, had a class referent from the start. Although this was not, by later standards, an unambiguous referent, it clearly referred to the lower classes, and to those whose deference was not ensured by traditional methods of rural social control. Sherlock Holmes' spectacular forays ${ }^{13}$ into the "criminal classes" of darkest London and beyond - beggars and opium-users, gangs and

\footnotetext{
12 Thompson 1966, p. 78-9, notes that Radicals and Chartists used the term “Mobility” for their demonstrations.

${ }^{13}$ Doyle 1981.
} 
race-touts, trade unions and secret societies - represent a fantasy means of engagement with the same anxieties. ${ }^{14}$

\section{New Kinds of Movement}

So much for "the social". But what is "the social movement"? Raschke writes of the "age of revolutions":

Movement became used as a metaphor for social change. The concept of movement also served for the deciphering of the inner connections of social development ('laws of movement')...

[E]arly liberals from the 1830 s spoke of themselves as movement in the sense of the only political direction which opposed the forces of inertia: of the 'party of movement' or the movement party...'

The 'social movement' is first discovered as the workers' movement: the concepts of social movement and workers' movement become accepted in the course of the 1840s. The concept is thus first applied to a movement with 'social' goals, i.e. to a collective with socialist answers to the 'social question'. The chronologically preceding liberal, national and democratic movement was not yet grasped with the concept of social movement; this only becomes possible with growing neutralisation of the term social movement. ${ }^{16}$

While Raschke, following 1980s usage, often defines movements in terms of issues and goals - "peace movement", "green movement" - as von Stein and the discussion above suggests, "social" referred as much or more to the agent: "workers' movement", "women's movement". This is important not just analytically but politically: the "social movement" of the 1840 s was not middle-class reformers seeking to soften the troubles of the poor, but the movement which included the poor themselves, a movement (as the first chapter of The making of the English working class has it) of "Members unlimited".

\footnotetext{
${ }^{14}$ Thomas 1998.

${ }^{15}$ The OED illustrates this meaning with quotes from the 1830s and 1840s, ranging from the more elitist ("The new doctrines of Radical Reformers, and of that section amongst political men denominated the Movement part” - De Quincey in 1835) to the more social ("The popular side in the great questions of English history, the side, in later language, of the movement” - Arnold in 1842). It derives the usage from French le parti du mouvement.

${ }^{16}$ Raschke 1988, 23.
} 
The social movement, then, was the self-activity of the "lower classes", or that part of their activity not controlled by elites, whether in fantasies of manipulation by outside agitators, or real versions from "Church and King" mobs to Methodism. That self-activity, in most of Europe, for most of the nineteenth century and indeed later, was illegal and subject to more or less violent repression, whether it consisted of open public meetings, political societies, an uncensored political press, trade unions, or demonstrations ${ }^{17}$. The monarchies and limited parliamentary regimes which dominated European politics did not take kindly to such activity ${ }^{18}$. This conflict structured themes shared by many movements of the time:

The rights to which reformers laid claim in 1819 were those of political organization, the freedom of the press, and the freedom of public meeting; beyond these three, there was the right to vote. ${ }^{19}$

- freedoms which, Thompson argues, working-class ideology continued to value in the longer term. ${ }^{20}$ Revolutionary periods saw such liberties widely taken, both as expressions of pressure from below and as concessions from above. They were periods in which this self-activity could be seen to have a visible effect on the world of wealth and power. Conservatives such as Weber, no less than radicals like Marx, expected that this selfactivity would prevail eventually.

"The social movement", then, took place over a long timescale, with bursts of activity and visibility in revolutionary periods, but otherwise present in that abstract and general sense of "society" outside such moments, whether as grievance and need, as potential and tradition, or as organization and "subversion".

This is the process whereby a 'class in itself' becomes a 'class for itself'. ${ }^{21}$ Here, in the lead-up to the revolutions of 1848, are Marx and Engels ${ }^{22}$ discussing the process:

\footnotetext{
${ }^{17}$ The more deferential and less autonomous structures of the petition or the cahiers de doléances, along with more ritualised expressions of popular feeling such as the funeral, were often more accessible for precisely this reason.

${ }^{18}$ Von Stein and Marx both experienced this personally - Marx being exiled from Germany and France; less dramatically, von Stein's support for the independence of Schleswig-Holstein cost him his job at the University of Kiel.

${ }^{19}$ Thompson 1966, 738.

${ }^{20}$ Thompson 1966, 805.

${ }^{21}$ Marx himself never seems to have used the latter phrase, but I think later Marxist usage is right to include the distinction. In Poverty of Philosophy he uses the phrase "class vis-à-vis capital", highlighting the constitutive role of conflict in arriving at conscious collective agency. Thanks to Colin Barker for pointing this out.

${ }^{22}$ In Marx and Engels, the word "movement”, unqualified, is used with various kinds of referent. It is used in a relatively trivial sense, as of "the anti-Church movement" (Marx in the Neue Oder-Zeitung, 28.6.1855), or "the Young-Hegelian movement" (German Ideology). It is used of "social movement organisations", as of "labour movements" (Condition of the Working Class in England), or of the Chartists (Engels in La Reforme, 10.1.1848). It is used for revolutionary and pre-revolutionary situations, as in "the revolutionary movement in
} 
The proletariat goes through various stages of development. With its birth begins its struggle with the bourgeoisie ... At this stage, the laborers still form an incoherent mass scattered over the whole country, and broken up by their mutual competition ... But with the development of industry, the proletariat not only increases in number; it becomes concentrated in greater masses, its strength grows, and it feels that strength more... Thereupon, the workers begin to form combinations (trade unions) against the bourgeois; they club together in order to keep up the rate of wages; they found permanent associations in order to make provision beforehand for these occasional revolts ... Now and then the workers are victorious, but only for a time. The real fruit of their battles lie not in the immediate result, but in the ever expanding union of the workers...

Another phrase for "the social movement", in other words, is class in the active sense. It is not that class is something other than, and explaining, the social movement: 'Let us not say that the social movement excludes a political movement. There is no political movement which is not at the same time social. ${ }^{23}$ Class, in an analysis like this, is an active term, developing from a situation of practical passivity (though even at the earliest stages there is struggle and competition) to where action is organized, conscious and coordinated. This theme lies at the heart of Thompson's Making of the English working class.

\section{Class and "the Social Movement"}

This section draws on the work of EP Thompson to illustrate how this understanding of "the social movement" is used by skilled hands to show how a class makes itself, the complex and changing structures of social movement, and social movement as development-in-struggle. Thompson deploys this understanding in a range of ways: leaving aside his more practically-directed works from the New Left and the peace movement, his historical work explores explicit political opposition, ${ }^{24}$ barely articulate

\footnotetext{
Germany” (Marx in Neue Rheinische Zeitung 184, Jan. 1849) or “the reform movement in France” (Engels in the Northern Star, 20.11.1847), and so on. It is also used in more general formulations: “the proletarian movement” (The Bakuninists at work), "the modern working-class movement” (On the history of early Christianity), or “the historical movement” (On the Jewish Question), which approach the sense indicated above.

${ }^{23}$ Marx 1963, p. 244.

${ }^{24}$ Thompson 1966.
} 
resistance, ${ }^{25}$ underlying normative aspects of popular culture, ${ }^{26}$ the biographies of a leading activist ${ }^{27}$ and a radical mystic, ${ }^{28}$ as well as theoretical polemic ${ }^{29}$.

Thompson and other Marxist historians were used by social movements authors like Tilly, ${ }^{30}$ but have not been recognised as significant theorists - perhaps because they work with a very different kind of theory. ${ }^{31}$ Thompson is occasionally cited as an "addon" to conventional social movement theory, for example by Mueller, ${ }^{32}$ J asper $^{33}$ and della Porta and Diani, ${ }^{34}$ but without being allowed to disturb its basic conceptualisations ${ }^{35}$. Conversely, movement participants often read and respond to his work in ways that most social movements authors are denied.

This section sketches Thompson's usage in Making, his most influential work and the one which shows best the range of his usage. Thus I am privileging his practical understanding over the explicit theoretical analysis in Poverty of Theory: since my argument is that "class" here refers to a particular understanding of "the social movement", the point is best made by showing that understanding at work. I start with an analysis of the structure of Making.

\section{How Does a Class Make Itself?}

The Making has three main sections. The first discusses the eighteenth-century inheritance of ideas, organisational practice and individuals which the nineteenth-century social movement would draw upon in its self-formation as the working class. That inheritance includes the organising tradition of Corresponding Societies, the language of radical Dissent, the moral economy and forms of popular resistance of the less articulate

\footnotetext{
${ }^{25}$ Thompson 1990.

${ }^{26}$ Thompson 1993a.

${ }^{27}$ Thompson 1976.

${ }^{28}$ Thompson 1993b.

29 Thompson 1978. Please note that I am not here considering the broader debate on Thompson's influence and arguments (e.g. MARHO 1983; Kaye 1984 and 1990; Stedman Jones 1983; Joyce 1993; Palmer 1994; McNally 1993). There are of course many questions which can be asked about a work now over fifty years old, and I would not accept every point of Thompson's arguments. My purpose here is rather to show how Thompson articulates the alternative understanding of “social movement”, and to argue for its fruitfulness as a mode of enquiry both academically and politically.

${ }^{30}$ For example Tilly 1995, p. 35.

${ }^{31}$ Thompson 1978.

${ }^{32}$ Mueller 1992.

33 Jasper 1997.

${ }^{34}$ Della Porta and Diani 1999.

${ }^{35}$ An earlier version of this chapter was prepared for a 2002 conference on the British Marxist historians and social movements.
} 
majority, developing political ideologies from the "Norman yoke" to the language of human rights, and the history of the proto-revolutionary wave of the 1790s.

These are presented, not as unquestioned "frames" within which subsequent organisers would have to locate themselves, but as tools which people used in the attempt to reshape their world, constraints on how they could express what they need to say, and models which they struggled to change. As Vester puts it, this is a sense of social movement as a learning process - not a top-down "banking model" of education, but one of practical learning and creativity. ${ }^{36}$ Another way of putting this is to say that participants were 'present at [their] own making', ${ }^{37}$ did not start as isolated rational individuals but as people who already had particular ways of understanding their situation and acting upon it.

"Movement", then, consists both of the development of rationality, in the sense of developing more accurate forms of self-understanding and more effective means of expressing and struggling to realize one's own needs - and of the blind alleys, the mistakes which Thompson discusses so eloquently, and which necessarily form part of the whole. In the 1960s, the language of triumphal progress was still powerful on the Left; nearly half a century later we might be more inclined to explore "causes which were lost" at earlier points: "After all, we are not at the end of social evolution ourselves. ${ }^{38}$

The second section discusses what might be called "movements from above", the processes of exploitation, of domination and of the creation of hegemony - not primarily as seen from above, but as experienced by the participants of the social movement, their own changing experience of their working lives, their 'standard of living', and the communities they lived in. Thus Thompson discusses the economic movement of proletarianisation, in all its complexity; the political and juridical movement of repression in its various forms; the cultural movement of Methodism and industrial labour discipline.

By contrast with social movement theory's normal assumption of a more or less static, neutral state against which social movements act, this model sees the actors of "the social movement" as from the start impacted by the (logically more powerful) movements from above - by the people and institutions who (outside revolutionary periods) drive the commodification of human beings as labour power, attempt to ensure

\footnotetext{
${ }^{36}$ Vester 1975.

${ }^{37}$ Thompson 1966, p. 9.

${ }^{38}$ Thompson 1966, p. 13.
} 
their containment within the given political order, and labour for their incorporation into appropriately subordinate ideologies.

Because the social movement is a threat, in other words, and a powerful one, the dominant order cannot exist without continually responding to it, and modifying its responses as and when they prove ineffective. Or, as Thompson put it: 'The notion of class entails the notion of historical relationship. ${ }^{39}$

As in other dialectical works of social movement research, such as Fantasia ${ }^{40}$ or Piven and Cloward, ${ }^{41}$ an adequate account of social movements has to be an account of this continuous conflict, whose previous truce-lines mark the borders from which new movements start:

... this question of the limits beyond which the Englishman was not prepared to be 'pushed around', and the limits beyond which authority did not dare to go, is crucial to an understanding of the period. ${ }^{42}$

The third section discusses the "new" working-class presence, as it shapes itself with this inheritance and in this struggle that it is born into. It focuses on the London crowd, the processes of unionising and direct action, political movements and the class consciousness which resulted from all this. The question of "outcomes", occasionally flagged in social movements research, acquires a different implication in these situations. Outcomes certainly include the victories gained or lost in the external conflict. But they also include, as the Manifesto stresses, the internal victories and defeats - the development or decline of participants' self-confidence, of their self-understanding, of the toolbox of organizing skills and political language they can draw on, and their alliances or isolation.

This is a point Hal Draper made famously in Two Souls of Socialism: ${ }^{43}$ that there is a fundamental difference between organising strategies which seek only to achieve redistribution and those which seek to change the balance of power, between

\footnotetext{
${ }^{39}$ Thompson 1966, p. 9

${ }^{40}$ Fantasia 1988.

${ }^{41}$ Piven and Cloward 1977.

42 Thompson 1966, p. 87.

${ }^{43}$ Draper, n.d.
} 
movements for the poor and movements of the poor - paralleling Thompson's discussion of the "tension between authoritarian and democratic tendencies" in Methodism. ${ }^{44}$

"The social movement" carries a different kind of assumption of rationality. Rather than assuming (with resource mobilisation theorists) that all individuals are equally rational (in the same egoistic and rather short-sighted way), or implying (as the "straw man" account of Marxism has it) that working class movements necessarily approximate rationality, this understanding sets out to ask how far and to what extent movement actors succeed in developing understandings and ways of acting which enable them to articulate their tacit knowledge, struggle effectively to meet their needs and remake the world on their terms. ${ }^{45}$ It does not assume that they always succeed in doing so; but it does assume that it is worth asking the question. ${ }^{46}$

\section{Excursus: Writing the Contemporary Social Movement}

It might be worth pausing briefly to imagine how this same structure might be used in an account of the contemporary social movement. Firstly, we might explore the various legacies of "1968" - on the inherited traditions of the Old Left and the fragile formations of the New Left, in the various histories of cadre groups and urban initiatives, counterculture and institutionalisation processes. ${ }^{47}$ Then we might look at the impact of the "class struggle from above" represented by disorganised capitalism and neo-liberal globalisation, linking these to the Thatcherite development of a right-wing "common sense", the formation of individualist strands within the "New Age" and so on. ${ }^{48}$ Thirdly, we might examine the "new social movements" in the 1970s and 1980s and their radicalisation in the $1990 \mathrm{~s},{ }^{49}$ alongside the history of the defeat of organised labour in the earlier period and the revival of grassroots struggle in the worldwide "anti-capitalist movement" from Chiapas and Caracas to Genova or February 2003, and finish with an

\footnotetext{
${ }^{44}$ Thompson 1966, p. 50. It is perhaps also possible to locate here the rational kernel lost in the noise of the caricaturing of the "new social movements" argument: that there is a fundamental difference between the "New Left" inheritance, of 1956 and 1968 , for which what is crucial is to change the structures of power, and that "Old Left", Stalinist or Social Democrat, for whom the goal was the achievement of state power by a different elite. That argument was fought out at earlier points within the socialist movement - by Luxemburg and Gramsci, for example - and reappears today between the technocratic "realists" of the established left and advocates of grass-roots organising.

${ }^{45}$ Wainwright 1994.

${ }^{46}$ Marxists expect the capacity for rationality to differ between different social classes; this explains the consistent failure of medieval peasant movements despite massive superiority in (potential) numbers, by contrast with twentieth-century peasant movements allied to workers and led by urban intellectuals (Rudé 1980) and working-class movements. The analysis may or may not be accurate, but it is reasonable to explore the issue rather than presuming or denying rationality by theoretical fiat.

${ }^{47}$ Cox 2001.

${ }^{48}$ Wainwright 1994.

${ }^{49}$ Epstein 1993.
} 
attempt to understand the fragmentation of US hegemony in Latin America and the Arab world and struggles around neo-liberal austerity in Europe.

This would not be a history of a single "movement" in the sense of the labour movement, the peace movement or the women's movement. It would be a history of shifting popular attempts to develop effective organization and theory, identities and everyday routines in the face of a powerful ruling-class offensive. It would place the interconnections between "movements" at the centre of the analysis, as against the fragmented discussion of single movements ${ }^{50}$. Most crucially, the story would not hold "class", or "gender", or "ethnicity", outside the analysis, as "independent variables" relating to "structure", any more than it would treat "globalisation" or "the Cold War" as outside factors.

\section{Thinking "the Social Movement"}

So far I've proposed an alternative tradition of theorizing "the social movement", deriving from the nineteenth century and continuing to the present day in some forms of Marxism. This approach theorises the self-creation of class, focusing on the development of practical rationality and the impact of other movements from above. If this active meaning of "class" embodies the sense of "the social movement", it is an interesting experiment to substitute "movement" for "class" in some of Thompson's famous formulations:

Movement happens when some people, as a result of common experiences (inherited or shared), feel and articulate the identity of their interests as between themselves, and as against other people whose interests are different from (and usually opposed to) theirs ...

Definitions such as Diani ${ }^{51}$ include these elements but lose the centrality of relationship. Or again:

[This book] is a study in an active process, which owes as much to agency as to conditioning. The social movement did not rise like the sun at an appointed time. It was present at its own making.

\footnotetext{
${ }^{50}$ Colin Barker points out rightly that we can usefully ask how some of the "fragments" (Rowbotham, Segal and Wainwright 1981) made significant steps forward which other parts of the wider "movement” adopted, fully or in part, such as "the understanding of women's liberation, or ecological questions, or anti-racism, or LGBT issues, and indeed religious oppression. In all of this and more, underlying images of 'the working class' also broadened and altered” (pers. comm.)

${ }^{51}$ Diani 1992.
} 
So much, one might say, for positivist attempts to "explain" or "predict" movements: explanation lies in people's own attempts to make sense of and transform their own situation - and in how other people have constructed that situation.

\title{
The Structures of Social Movement
}

These are broad-brush statements. How does the analysis work at a finer level? Here is Thompson discussing the varying relationship between community structures, political organization, and ideology:

\begin{abstract}
'Radical London' has always been more heterogeneous and fluid in its social and occupational definition than the Midlands or Northern centers grouped around two or three staple industries. Popular movements in London have often lacked the coherence and stamina which results from the involvement of an entire community in common occupational and social tensions. On the other hand, they have generally been more subject to intellectual and 'ideal' motivations... London Radicalism early acquired a greater sophistication from the need to knit diverse agitations into a common movement. ${ }^{52}$
\end{abstract}

Far from the one-to-one relationship between occupational class and social movement imagined by naïve sociological critiques of Marxism, Thompson shows how forms of active self-expression have different relationships to occupational situations. This same kind of "layered" thinking appears throughout:

If we are concerned with historical change we must attend to the articulate minorities [such as the English Jacobins]. But these minorities arise from a less articulate majority whose consciousness may be described as being, at this time, 'sub-political'... (1966: 59)

This introduces a discussion of individual breaking of despised laws, popular riots and insurrections, and so on as expressions of this consciousness. Such an approach runs radically counter to the kind of social movement writing in which "movement" is defined as a particular type of organisation, and what falls "below" this (e.g. popular culture, rioting), "above" it (e.g. political parties, revolutions) or come to that "beside" it (e.g. popular religion) are ruled as falling on the territory of some other sub-discipline; the interrelationships are central to understanding.

\footnotetext{
52 Thompson 1966, 23; compare pp. $513-514$.
} 


\section{Social Movement as Development}

This "layered" approach is also a developmental model: time and again Thompson makes comments such as "behind every form of popular direct action some legitimizing notion of right is to be found' or '[such riots] required more preparation and organization than is at first apparent. ${ }^{.53}$ The relationship, between the articulate minorities and less articulate majority, is not one between structure and agency, or between objective class and class consciousness. It is between different degrees of awareness and self-activity, between a broader, shared culture in which past gains are sedimented as popular traditions and a more conscious and political sphere from which at times new traditions are successfully developed:

[P]opular revolutionary crises ... arise from exactly this kind of conjunction between the grievances of the majority and the aspiration articulated by the politically conscious minority. ${ }^{54}$

These "conjunctions" are not between fixed categories, but between situations which movements struggle to change:

[The London mob] was a transitional mob, on its way to becoming a selfconscious Radical crowd; the leaven of Dissent and of political education was at work, giving to the people a predisposition to turn out in defence of popular liberties, in defiance of authority ...55

Similar analyses, of the tensions and developments within popular attempts at selfactivity, recur in the discussion of popular Methodism (ch. 11) and of the Westminster election committee (ch. 13). This sense of movement as change is one of the greatest strengths of the Making:

[Between 1815 and 1850] [t] he reformers ceased to fear 'the mob', while the authorities were forced to build barracks and take precautions against the 'revolutionary crowd'. This is one of those facts of history so big that it is easily overlooked, or assumed without question; and yet it indicates a major

\footnotetext{
53 Thompson 1966, p. 73 and 70.

54 Thompson 1966: 184.

55 Thompson 1966, p. 75
} 
shift in emphasis in the inarticulate, "sub-political" attitudes of the masses. (1966: 85)

Thompson repeatedly draws our attention to the development of crucial qualities such as autonomy, organization, and self-awareness:

Luddism [is] a manifestation of a working-class culture of greater independence and complexity than any known to the eighteenth century. The twenty years of the illegal tradition before 1811 are years of a richness at which we can only guess; in particular in the trade union movement, new experiments, growing experience and literacy, greater political awareness, are evident on every side.$^{56}$

"Movement" is no bad metaphor for this; and movement can go in both directions, undermining these achievements:

The persecution [of 1798] tore the last Jacobin intellectuals apart from the artisans and labourers... At the other pole, we have the disorganized and persecuted working men, without national leadership, struggling to maintain some kind of illegal organization. ${ }^{57}$

If movements are learning processes, learning takes time and is sedimented in ideas, people and organisations which are fragile and subject to all sorts of reversals.

\section{Movement in Struggle}

This development spans multiple "movements", in the language of contemporary social movements theory. One of Thompson's great strengths is his ability to integrate the history of separate developments, to find links between the Painites of the 1790s and the Luddites of the 1810s, or between Luddites and later trade unionists; but also the coming together of different traditions within a single movement:

... when Luddism came to Lancashire it did not move into any vacuum. There were already, in Manchester and the larger centers, artisan unions, secret

\footnotetext{
${ }^{56}$ Thompson 1966, p. 658

${ }^{57}$ Thompson 1966, p. 193-94
} 
committees of the weavers, and some old and new groups of Painite Radicals, with an ebullient I rish fringe. ${ }^{58}$

Like orthodox social movements theory, Thompson explores the means of organising available, but marks these down as classed: 'Working men were not, after all, strangers to these forms of activity; couriers passed regularly, on illicit trade union business, between all parts of Britain' ${ }^{59}$

On the other side, the development of the popular movement stimulates fear in the ruling classes:

Here is something unusual - pitmen, keelmen, cloth-dressers, cutlers ... working men in villages and towns over the whole country claiming general rights for themselves. It was this - and not the French Terror - that threw the propertied classes into panic. ${ }^{60}$

Conversely: ' $\ldots$ at each point where [the worker] sought to resist exploitation, he was met by the forces of employer or State, and commonly both. ${ }^{61}$

There is a dialectic between two movements, from above and below, not an interaction between multiple, discrete movements and a neutral state. The "movement from above", in the 1790s, included state repression, the encouragement of "Church and King" mob violence, publications, and organizations. ${ }^{62}$

Indeed at times - in the struggle for hegemony in Methodism, and the ambiguous relationship of middle-class nonconformity and radicalism to plebeian rebellion - these are struggles happening within a single organisational context: ' $\ldots$ the working-class community injected into the chapels its own values of mutual aid, neighbourliness and solidarity.'. ${ }^{63}$ Or in different organisations of the same movement:

In [the Primitive Methodists] and other sects, the local preachers made the Church their own; and for this reason these sects contributed far more

\footnotetext{
${ }^{58}$ Thompson 1966, p. 651.

${ }^{59}$ Thompson 1966, p. 183.

${ }^{60}$ Thompson 1966, p. 114.

${ }^{61}$ Thompson 1966, p. 218.

${ }^{62}$ Thompson 1966: p. 123.

${ }^{63}$ Thompson 1966, p. 431.
} 
directly to the later history of trade unionism and political Radicalism than the orthodox Connexion. ${ }^{64}$

Ultimately, Thompson's history shows the development of a single movement (struggling against a more powerful and opposing movement). That movement is embodied in different themes (industrial, political, religious, ritual) at different times and places, sometimes formed into complex alliances, sometimes fragmented and isolated, but developing and changing. It is not a single network, with a common shared identity, as in Diani's definition. ${ }^{65}$ Rather, such networks and identities are themselves occasional achievements in the developing self-consciousness and self-activity of the social movement: 66

... the outstanding fact of the period between 1790 and 1830 is the formation of 'the working class'. This is revealed, first, in the growth of classconsciousness: the consciousness of an identity of interests as between all those diverse groups of working people and as against the interests of other classes. And, second, in the growth of corresponding forms of political and industrial organization. By 1832 there were strongly based and self-conscious working-class institutions - trade unions, friendly societies, educational and religious movements, political organizations, periodicals - working-class intellectual traditions, working-class community-patterns, and a workingclass structure of feeling. ${ }^{67}$

To make this kind of analysis - and explain why some "constructions of identity" work Thompson has to look behind identity to interests: while by the end of the period these interests were part of the movement's shared identity, it was not so at the outset. His account could not be written without that judgement, which rests on a broader analysis as to the the situations from which people take action.

The "straw man" version of Marxism - first there are classes, and then they do social movements - is correct to recognise that the Marxist account of "social movement" is not

\footnotetext{
${ }^{64}$ Thompson 1966, p. 436.

${ }^{65}$ Diani 1992.

${ }^{66}$ This recognition of the processual nature of identity has made its way into constructivist studies from Marxism, via Touraine (e.g. 1981) and Melucci (e.g. 1989). What is usually lost (other than acknowledgement of its origin) is a recognition that this is what good organisers always tried to do: to build a broader sense of "we", not for its own sake but as a way of creating broader and more radical coalitions capable of challenging powerfully-supported structural inequalities. For precisely these reasons, late nineteenth-century socialists engaged with trade union organisation, international solidarity, resistance to oppression, support for suffragettes, and come to that radical movements in art and literature.

${ }^{67}$ Thompson 1966, p. 212-13.
} 
a sub-discipline which can bracket questions about the wider society. It fails to understand, though, that the Marxist account is one of movements as class struggle: not something which pre-existing classes go out and do, but the conflict where classes are formed: '... class is a relationship, and not a thing. ${ }^{68}$

Researchers often write of past movements as though the existence of a self-conscious and organised working-class was somehow a natural feature of late nineteenth- or early twentieth-century society; a careful reading of the Making shows rather how far this existence as organised subject was a historical achievement.

\section{The Social Movement in Contemporary I reland}

'Scientific socialism' was only used in opposition to utopian socialism, which wants to attach the people to new delusions, instead of limiting its science to the knowledge of the social movement made by the people itself [Erkenntnis der vom Volk selbst gemachten sozialen Bewegung] ${ }^{69}$

Finally, I want to discuss the contemporary self-organisation of working-class communities in the Republic of Ireland. This is a large and complex process, and until recently the single largest part of the social movement in terms of active participants. This movement includes community development, in the sense of a codified and selfaware model of bottom-up practice applied to a range of different campaigns and organizations; a more varied sphere of community politics, in the sense of locally-based forms of formal action expressing working-class needs; an underlying community culture and identity; and specialized activities such as community education (participatory adult education serving popular needs) and community media (press, radio and video groups). Characteristic of all these is a double grounding in local working-class communities: as the expression of the identity and needs of these communities, but also as movements of these communities, in the sense of a shared culture of radical-democratic organization. ${ }^{70}$

\footnotetext{
${ }^{68}$ Thompson 1966, p. 11.

${ }^{69}$ Marx 1974, p. 337.

${ }^{70}$ This movement is now starting to have some substantial attention from participant researchers, such as Bridgeman (2010); Geoghegan (2000; Geoghegan and Cox 2001, Powell and Geoghegan 2004); Gillan (2010a, b); Lyder (2009); Mullan (Mullan and Cox 2000); Punch (2009); as well as Boyle (2005) and my own work in the area (2001, 2007, 2010). I have been fortunate enough to work with some truly remarkable activists in movement and academic contexts over the last fifteen years, and this section draws on these experiences and discussions.
} 


\section{The Branches of a Single Tree}

This is an eminently Thompsonian development, and cannot be understood separate from other aspects of working-class self-organisation in Ireland. These are many and varied. They include economic forms of organisation, notably trade union, credit union and some co-operative traditions. They include political organisation, in the contested territory of socialist, nationalist and labour parties, ${ }^{71}$ where battles for hegemony, between autonomous and co-opted modes of politics, are constant. They include the churches and other forms of voluntary association where working-class contents conflict with forms created from above.

And they include other popularly-based campaigns: some environmental justice campaigns, $^{72}$ some peace activism (especially around the sensitive issue of Irish "neutrality"), some feminist organization (notably community women's groups ${ }^{73}$ ), some grass-roots urban republicanism and some international solidarity activism. At times these stand separately; at others, powerfully, they come together, ${ }^{74}$ as partly in the struggle over Shell's gas pipeline at Rossport.

Rather than see these, with orthodox "social movement studies", as so many different movements, it makes more sense to start from their interconnections, in terms of participants, political traditions, organising skills and shared culture. In this perspective, we have so many different aspects of the same social movement, whose linkages, mergers and separations can be understood in a historical perspective: not that this movement died, and this movement was born, but that the one movement changed its shape. $^{75}$

I mplicit within either perspective is a political analysis. The one I am arguing for sees the broader sense of unity and direction as something which may be inarticulate or contested at one time, but widely shared and explicitly stated at other times. It assumes that there are ultimately common concerns and needs, and while participants may not always be able to realise those fully they will continue to take action around them.

Resisting the ahistorical assumption - in Europe, where most states have been created or remade within living memory and with the substantial participation of popular

\footnotetext{
${ }^{71}$ Hanley and Millar 2009.

${ }^{72}$ Allen 2004.

${ }^{73}$ Coulter 1993.

${ }^{74}$ Cox 2007.

${ }^{75}$ Cox 2002, 2006 and 2010.
} 
movements - that the framework of state and society is fundamentally given, this perspective allows movements to come together to challenge the wider picture, as when Irish peasants won the land and a nationalist movement achieved partial independence, and to move from what are conventionally separated as "social movement studies" into revolutions.

\section{Common Sense and Good Sense}

While such moments are rare, movements themselves refuse to remain neatly boxed up. General concepts of class, revolutionary rhetoric, international connections and an awareness of this shared heritage are widely, if unevenly, felt. And individual activists make these connections practically, in the course of their lives, but also in the course of their week. This has to be taken seriously: not only how movements present themselves within the system when lobbying or seeking funding, but also how they see themselves.

As Geoghegan shows, working-class community activists routinely think and speak in two ways: within the limited terms and language set by state funding agencies and their own boards of management, and in the more politicised and class-oriented understandings which underpin their own practice. ${ }^{76}$ In situations where even most paid participants were on short-term and low-waged contracts and were deeply cynical about official processes, their involvement 'in and against the state' was best understood as one aspect of their practice rather than the whole: ${ }^{77}$ the bigger picture struggles with the organisational forms, and not only in Ireland. ${ }^{78}$

With Gramsci, we can say that there is often a tension between the hegemonic "common sense" expressed by particular organisations, and the grassroots "good sense" which the movement as a whole seeks to articulate. This relationship - and the tension between the narrowly organisational perspective and the broader goal of transformation of state and society - is a constitutive one, and not only for this movement. We miss something important when we separate off the two into different fields of thought.

In Ireland, community movements were instrumental in the 1980s in pushing for "partnership" with the state, in an attempt to force it to live up to its claims to be an agent of developmental modernisation. In the crisis of I rish neoliberalism, partnership is being abandoned from above. Participants who had fully experienced its limitations but

\footnotetext{
${ }^{76}$ Geoghegan 2000.

${ }^{77}$ London-Edinburgh Weekend Return Group 1980.

${ }^{78}$ Wainwright 2009.
} 
accepted them on a day-to-day basis now have less and less to defend; many are returning to a larger sense of purpose and loyalty even as they struggle to find better organisational forms for their own struggles. ${ }^{79}$

The legacy of clientelist partnership is not a trivial one; it was a costly mistake, and after two decades many more experienced participants will not be willing or able to return "outside". The weakness of popular responses to cuts and IMF bailout to date show the depth of the organisational failure of the Irish movement; an adequate response will come not from the organisations but from the wider good sense articulated by the movement, which is now able to come to the fore. ${ }^{80}$ Over the past two years I experience activists I meet as angry and having taken defeats, but not defeated; there is a willingness to fight, and an energy for new approaches even where it is not clear what shape the movement will take.

\section{The Perspective of Participants Themselves}

As all this implies, these are articulate, literate and highly-reflective movements, with a number of institutions of self-education: the training grounds of the left and republican parties, the trade and credit unions, the structures of community education and the training programmes of community workers, the written and broadcast expression of the community media and the traditions of oral history within specific communities.

These movements are not only objects of theory, they are also creators of theory. The relationship between Thompson and the adult education movement is well-known; but his writing is also informed by his participation in the Communist and New Left movements, his involvement with East European dissidence and West European antinuclear organization, and (indirectly, but not irrelevantly) by his familiarity with movement thought from earlier generations, from the Muggletonians and the English Jacobins to Blake and Morris. As O'Connor wrote of Raymond Williams: '... he writes this but these political intentions and movements write him'. ${ }^{81}$

\footnotetext{
${ }^{79}$ Cox 2010.

${ }^{80}$ Tellingly, for example, Community Media Network decided already in 2008 to pull back from the organisation-building mode of constructing community television in favour of a return to grassroots "capacity-building” work with working-class communities (Gillan 2010). See also Cox 2011.

${ }^{81}$ O’Connor, 1989: 125-6.
} 
Social movement studies, with its scholastic isolation of "theorists" for study, has little place for this kind of perspective, and at best grants movements the right to propose new matter for scholarly consideration. But movements consist of conscious, reflective people, who are inevitably thinking beyond taken-for-granted routines, both in the direction of the unorganised and in the direction of the future.

This is what enables us to call them movements: they are not simply the reproduction of unreflected activity, but creative processes which - in order to mobilize the unmobilised and change the world - have to keep on reaching beyond themselves. They are constantly in debate over "what should we do?", contesting contested assumptions as to how the world is. They continually generate "how to do it" theory, whether in cultural traditions, informal apprenticeship and "mentoring" situations, or formal training programmes and manuals: ${ }^{82}$ 'Thus working men (sic) formed a picture of the organization of society, out of their own experience and with the help of their hard-won and erratic education.... ${ }^{83}$

Such pictures, we might add, contributed massively to the understandings which figures like Marx, Durkheim or Weber would later draw on, formalise and elaborate.

\section{In Conclusion}

In this chapter I have attempted as far as possible to avoid "theoretical imperialism", and to allow nineteenth-century language, EP Thompson's mid-twentieth-century writing and the struggles of contemporary working-class community activists to inhabit their own worlds rather than attempt to squeeze them all into tightly-formalised concepts. These different languages express much hard-won learning; and we easily lose information if we standardise too quickly on our own terms rather than first listening closely to what is said. ${ }^{84}$

This chapter has argued that a broader conception of social movement sees it as encompassing the full scale of collective human agency, from "everyday resistance" and "hidden transcripts" to revolutions and struggles over hegemony; that we should see the forms or categories which this takes as historically conditioned, including their internal differentiation, relationships between different parts of the movement and struggles with

\footnotetext{
${ }^{82}$ Barker and Cox 2002; Cox 1998.

${ }^{83}$ Thompson 1966, p. 782.

${ }^{84}$ With Alf Nilsen (and in our joint chapter in this volume) I have attempted a more formal statement of what I think are the common features of the alternative conception.
} 
more powerful opponents; and that this is grounded in material reality, needs and interests.

This approach, perhaps, has the merit of highlighting not just what social movements do, but what they do it for - and of recalling the important fact that sometimes they win by transforming the structures and categories by which they are supposed to be constrained and defined. As researchers, one of our tasks is to theorise in ways adequate to this reality - and, perhaps, in dialogue with participants and their own modes of thought.

\section{REFERENCES}

Allen, Robert 2004, No Global: the People of Ireland Versus the Multinationals, London: Pluto.

Barker, Colin and Laurence Cox 2002, 'What Have the Romans Ever Done for Us? Activist and Academic Forms of Movement Theorizing', in Eighth International Conference on Alternative Futures and Popular Protest, edited by Colin Barker and Mike Tyldesley, Manchester: Manchester Metropolitan University, available at http: //eprints. nuim. ie/428/.

Douglas Bevington and Chris Dixon 2005, 'Movement-Relevant Theory: Rethinking Social Movement Scholarship and Activism', Social Movement Studies, 4, 3: 185-208.

Boyle, Mark 2005, 'Sartre's Circular Dialectic and the Empires of Abstract Space: A History of Space and Place in Ballymun, Dublin', Annals of the Association of American Geographers, 95, 1: 181-201.

Bridgeman, Jean 2010, 'A Matter of Trust: The Politics of Working-Class Self-Education', Interface, 2, 1: 154-167.

Coulter, Carol 1993, The Hidden Tradition: Feminism, Women and Nationalism in I reland, Cork, Cork University Press.

Cox, Laurence 1998, 'Gramsci, Movements and Method: The Politics of Activist Research', in Fourth International Conference on Alternative Futures and Popular Protest, edited by Colin Barker and Mike Tyldesley, Manchester Metropolitan University, available at http://eprints. nuim. ie/442/. 
Cox, Laurence 2001, 'Globalisation from Below? 'Ordinary People', Movements and Intellectuals from Seattle to Genova', paper to William Thompson summer school, Cork, available at http://eprints. nuim.ie/1530/.

Cox, Laurence 2006, 'News from Nowhere: The Movement of Movements in Ireland', in Social Movements and Ireland, edited by Liam Connolly and Niamh Hourigan, Manchester: Manchester University Press.

Cox, Laurence 2007, 'Building Utopia Here and Now? Left and Working-Class Utopias in Ireland', Ecopolitics online 1, 1: 123-132.

Cox, Laurence 2010, 'Another World is Under Construction? Social Movement Responses to Inequality and Crisis', Irish Left Review, May 17, available at http: // www. irishleftreview.org/2010/05/17/world-construction-social-movementresponses-inequality-crisis/.

Cox, Laurence 2011, 'Popular Responses to the Irish Crisis and the Hope for Radical Change: Organic Crisis and the Different Meanings of Counter-Hegemony', paper to Alternative Futures and Popular Protest 16, Manchester Metropolitan University, April 2011.

della Porta, Donatella and Mario Diani (1999): Social Movements: An Introduction, Oxford: Blackwell.

Diani, Mario 1992, 'The Concept of Social Movement', Sociological Review, 40, 1: 1-25.

Doyle, Arthur Conan 1981, The Penguin Complete Sherlock Holmes, Harmondsworth: Penguin.

Draper, Hal n.d., 'The Two Souls of Socialism', available online at http://www. marxists.org/archive/draper/1966/twosouls/.

Epstein, Barbara 1993, Political Protest and Cultural Revolution: Non-Violent Direct Action in the 1970s and 1980s, Berkeley, University of California Press.

Fantasia, Rick 1988, Cultures of Solidarity: Consciousness, Action, and Contemporary American Workers, Berkeley: University of California Press. 
Geoghegan, Martin 2000, Meaning, Action and Activism: Community Development as a Social Movement, MA thesis, Waterford Institute of Technology.

Geoghegan, Martin and Laurence Cox 2001, 'Outside the Whale: (Re)thinking Social Movements and the Voluntary Sector", in Seventh International Conference on Alternative Futures and Popular Protest, edited by Colin Barker and Mike Tyldesley, Manchester: Manchester Metropolitan University, available at www.iol.ie/ mazzoldi/toolsforchange/afpp/afpp7.html.

Gillan, Margaret 2010b, 'Class and Voice: Challenges for Grassroots Community Activists Using Media in 21st Century Ireland', Interface 2, 2: 126-148.

Gillan, Margaret 2010a, Class, Voice and State: Knowledge Production in Self-Organised Working-Class Activity and the Politics of Developing Community Television in Ireland, PhD thesis, Dept of Sociology, NUI Maynooth, online at http://eprints.nuim.ie/2293/.

Hanley, Brian and Scott Millar 2009, The Lost Revolution: The Story of the Official IRA and the Workers Party, London: Penguin.

Hutton, Ronald 1999, The Triumph of the Moon: A History of Modern Pagan Witchcraft, Oxford: Oxford University Press.

Jasper, James M. 1997, The Art of Moral Protest: Culture, Biography and Creativity in Social Movements, Chicago: University of Chicago Press.

Joyce, Patrick 1993, Visions of the People: Industrial England and the Question of Class, 1848-1914, Cambridge: Cambridge University Press.

Kaye, Harvey 1984, The British Marxist Historians, Cambridge: Polity Press.

Kaye, Harvey and McClelland, Keith (eds) 1990, E. P. Thompson: Critical Perspectives, London: Polity Press.

Linebaugh, Peter and Marcus Rediker 2000, The Many-Headed Hydra: Sailors, Slaves, Commoners, and the Secret History of the Revolutionary Atlantic, Boston: Beacon. 
London-Edinburgh Weekend Return Group 1980, In and Against the State, London: Pluto.

Lyder, André 2005, Pushers Out: The Inside Story of Dublin's Anti-Drugs Movement, Bloomington: Trafford Publishing.

Mueller, Carol McClurg 1992, 'Building Social Movement Theory', in Frontiers in Social Movement Theory, edited by Aldon Morris and Carol McClurg Mueller, New Haven: Yale University Press.

MARHO, the Radical Historians Organisation 1983, Visions of History, Manchester: Manchester University Press.

Marx, Karl 1963, Selected Writings in Sociology and Social Philosophy, Harmondsworth: Penguin.

Marx, Karl 1974, The First International and After, Harmondsworth: Penguin.

McAdam, Doug, Charles Tilly, and Sidney Tarrow, S. 2001, Dynamics of Contention, Cambridge: Cambridge University Press

McNally, David 1993, ‘EP Thompson: Class Struggle and Historical Materialism’, International Socialism Journal 61, available at http://pubs. socialistreviewindex.org.uk/isj61/mcnally.htm

Melucci, Alberto 1989, Nomads of the Present: Social Movements and Individual Needs in Contemporary Society, Philadelphia: Temple University Press.

Meyer, David and Sidney Tarrow 1998: The Social Movement Society: Contentious Politics for a New Millennium, Lanham MD: Rowman and Littlefield.

Mullan, Caitríona and Laurence Cox 2000, 'Social Movements Never Died: Community Politics and the Social Economy in the Irish Republic', paper to BSA/ISA conference 'Are Social Movements Reviving?', Manchester, November 2000, available at www. iol.ie/ mazzoldi/toolsforchange/afpp/isa. html.

O'Connor, Alan 1989, Raymond Williams: Writing, Culture, Politics, Oxford: Blackwell. 
Palmer, Bryan 1994, E. P. Thompson: Objections and Oppositions, New York: Verso.

Piven, Frances Fox and Richard Cloward 1977, Poor People's Movements: Why They Succeed, How They Fail, New York: Pantheon.

Powell, Fred and Martin Geoghegan 2004, The Politics of Community Development: Reclaiming Civil Society or Reinventing Governance?, Dublin: A\&A Farmar.

Punch, Michael 2009, 'Contested Urban Environments: Perspectives on the Place and Meaning of Community Action in Central Dublin, Ireland, Interface 1, 2: 83-107.

Raschke, Joachim 1988, Soziale Bewegungen: Ein Historisch-Systematisches Grundriss, New York/Frankfurt am Main: Campus.

Rowbotham, Sheila, Lynne Segal and Hilary Wainwright 1981, Beyond the Fragments: Feminism and the Making of Socialism, London: Merlin.

Rudé, George 1980, I deology and Popular Protest, London: Lawrence and Wishart.

Stedman-Jones, Gareth 1983, Languages of Class: Studies in English Working-Class History, 1832-1982, Cambridge: Cambridge University Press.

von Stein, Lorentz 1850 - 1855, Die Sociale Bewegung in Frankreich: Von 1789 bis auf unsere Tage, Leipzig: O. Wigand.

Thomas, Donald 1998, The Victorian Underworld, London: John Murray.

Thompson, E. P. 1966, The Making of the English Working Class, Harmondsworth: Penguin.

Thompson, E. P. 1976, William Morris: Romantic to Revolutionary, New York: Pantheon.

Thompson, E. P. 1978, The Poverty of Theory and Other Essays, London: Merlin.

Thompson, E. P. 1990, Whigs and Hunters: Origins of the Black Act, Harmondsworth: Penguin.

Thompson, E. P. 1993a, Customs in Common, Harmondsworth: Penguin. 
Thompson, E. P. 1993b, Witness Against the Beast: William Blake and the Moral Law, Cambridge: Cambridge University Press.

Touraine, Alain 1981, The Voice and the Eye: an Analysis of Social Movements, Cambridge: Cambridge University Press.

Vester, Michael 1975, Die Entstehung des Proletariats als Lernprozess: die Entstehung antikapitalistischer Theorie und Praxis in England 1792 - 1848, Frankfurt: Europäischer Verlagsanstalt.

Wainwright, Hilary 1994, Arguments for a New Left: Answering the Free-Market Right, Oxford: Blackwell.

Wainwright, Hilary 2009, Reclaim the State: Experiments in Popular Democracy, London: Seagull.

Williams, Raymond 1983, Keywords: A Vocabulary of Culture and Society, London: Fontana. 